\title{
INFERTILITY MANAGEMENT THROUGH AYURVEDA SHODHANA KARMA- A CASE REPORT
}

\author{
Pooja .S.Dhuria ${ }^{1}$ \\ ${ }^{I}$ PG scholar, Department of Prasuti Tantra and Streeroga, Sri Dharmasthala Manjunatheshwara College of Ayurveda \\ and Hospital ,B M Road ,Thanniruhalla,Hassan-573201 \\ Prathima ${ }^{2}$ \\ ${ }^{2}$ Associate Professor, Department of Prasuti Tantra and Streeroga,Sri Dharmasthala Manjunatheshwara College of \\ Ayurveda and Hospital ,B M Road,Thanniruhalla,Hassan-573201
}

DOI: https://doi.org/10.36713/epra3879

\begin{abstract}
Purpose: The World Health Organization (WHO) estimate that 60 to 80 million couples worldwide currently suffer from infertility. The female infertility has becomes major issue in current scenario due to the increasing number of incidences day by day. In India alone many couples suffers from infertility. The treatment options of female infertility also improving and traditional system of medicine such as Ayurveda describes female infertility broadly with its treatment protocol. Infertility affects women of reproductive age group all over the world. The infertility can be primary or secondary. Panchakarma can treat infertility successfully using various methods along with Ayurvedic formulations.

Methodology: A Female Patient of 26 year came to OPD presenting with the complaints of inability to Conceive. Patient was complaining of delayed and heavy menstrual Periods as a clinical feature of PCOD which was diagnosed in USG report Patient was treated with Panchakarma and Ayurvedic Oral medicine. Vamana karma was done and in next Consecutive Cycle Patient got conceived.

Result: In next Consecutive Cycle Patient got conceived and she is under regular Antenatal check up.

Conclusion: Infertility is defined as a failure to conceive within one year or more years of regular unprotected coitus. PCOD occurs due to an imbalance caused by any of the three Doshas which affect the fertility of the female. These causes increase of Kapha and Vata Dosha and cause the formation of the multiple cysts in ovaries leading to anovulatory periods followed by obesity, hirustitsm. Vamana Karma helps in Strotoshudhi and help in the kapha disorders. Pushpadhanwa rasa act on the Manashanthi and Garbhakrut. Ashwagandha Ksheerpaka acts as Garbhasthapaka and Rasayana. The present study reveals the effective management of infertility associated with PCOD was managed by Shodana and Garbhasthapaka oushadhi

KEYWORDS: PCOS, Artava Dusti, Sthoulya, Infertility
\end{abstract}




\section{INTRODUCTION}

According to the Indian Society infertility currently affect about 10 to $14 \%$ of the Indian population. Poly Cystic Ovarian Disease (PCOD) is a disease characterized by multiple cysts in the ovaries. It is most common among women between the ages of 18 to 40 years. It affects $9.13 \%$ to $36 \%$ of women of reproductive age.

The exact cause of PCOD is unknown it may be due to hormonal imbalance, insulin resistance, family history and lifestyle or environmental factors. Common symptoms of PCOD are menstrual abnormalities, hirsutism, acne, obesity. Diagnosis of PCOD is done by laboratory tests such as Hormonal assay, Thyroid profile, Lipid profile, Glucose tolerance invasive tests such as ultrasonography and Laparoscopy. Women with PCOD have a higher risk of developing endometrial cancer, breast cancer, cardiac disease, diabetes, high blood pressure.

In Ayurveda exact correlation cannot be made but lakshans will be similar to rasa nimittaja vyadhis proper understanding of Prakruti and Agni treating according to that will yields good result.

\section{CASE PRESENTATION}

A female patient of 26 year married women came to OPD of Prasuti - Stree Roga, Shri Dharmasthala Majunatheshwara College of Ayurveda and Hospital with chief complaints of Anxious to conceive since 5 year of marital life with Prolonged bleeding associated with pain during menstruation and weight gain $\left(28.6 \mathrm{~kg} / \mathrm{m}^{2}\right)$ since 3 years after the detail evaluation she was diagnosed with PCOD. For this she took treatment but got no relief. So for further management she approached to our hospital.

Her family history was found normal. Her diet was more oily, spices and included day sleep .It was also recognized that her psychological feature were likely to impact. The rest of her physical exam was unremarkable. Blood pressure was $120 / 80 \mathrm{mmHg}$, Pulse rate was 82/minute, Weight-70.2 kg and Height $154 \mathrm{~cm}$.

On examination:

\begin{tabular}{|l|l|l|l|l|l|l|}
\hline $\begin{array}{l}\text { General } \\
\text { Examination }\end{array}$ & Built & Nourishment & Tongue & Height & Wight & BMI \\
\hline & Overweight & Well nourished & Coated & $157 \mathrm{~cm}$ & $70.2 \mathrm{~kg}$ & $28.5 \mathrm{~kg} / \mathrm{m}^{2}$ \\
\hline
\end{tabular}

\begin{tabular}{|l|l|}
\hline Local Examination & B/L:Breast Soft,Symmetrical ,NAD \\
& P/S:Cervix mild erosion of upper lip mild white discharge \\
& P/V:uterus normal size \& fornices free \\
\hline
\end{tabular}

Blood investigations: All routine investigations including hormonal assay were said to be normal.

Husband parameter semen analysis was normal.

Ultrasonography : A uterine ultrasound was performed, which revealed a normal appearing uterus,

TREATMENT: Vamana shodana karma was planned.

\begin{tabular}{|l|l|c|l|}
\hline SR.NO & \multicolumn{1}{|c|}{ Name of the procedure } & Day & \multicolumn{1}{c|}{ Drugs used } \\
\hline 1 & Deepana pachana & 3 & Chitrakadi vati 1 tid , panchakola phanta 50 ml tid \\
\hline 2 & Snehapana & 4 & $\begin{array}{l}\text { Pancha Tiktaka Ghrita (Starting from 30 ml then } \\
\text { increased gradually up to Samyak Sneha-Siddhi Lakshan } \\
120 \mathrm{ml})\end{array}$ \\
\hline 3 & $\begin{array}{l}\text { Abhyanga followed by Baspa sweda and } \\
\text { Ushna jala snana }\end{array}$ & 2 & Ksheerabala taila \\
\hline 4 & $\begin{array}{l}\text { Vamana karma (with Madanaphala 10 } \\
\text { gm+Pippali 1 gm+Yashti madhu 5 } \\
\text { gm+Saindhava 5 gm+Vacha 2gm }\end{array}$ & & As per Koshta and Bala of Rugna \\
\hline
\end{tabular}

Vamana Vegas -8 pravara shudhi kaphantiki, After vamana Samsarsajana karma was followed for 5days. Table 2: Garbha Sthapana Aushadhi

\begin{tabular}{|c|c|c|c|}
\hline Sr.no & Name of the drugs & Dose & Anupana \\
\hline 1. & Pushpadhanwa Rasa & 2 TID & Ushna jala \\
\hline 2. & Aswaghanda Ksheerapaka & BD & $50 \mathrm{ml}$ \\
\hline
\end{tabular}


Pathya Ahara-Plenty of fluids, tila laddu, Shuti jala, hot water, more vegetabls, fruits,

Pathya Vihara-Regular exercise, walking, yoga, Pranayama, She was also advised for intercourse during ritukala from 12 to 20 day of menstrual cycle. ApathyaAhara-Backery food, junk food, sweet, curd. Apathya Vihara-Day sleep, late sleep, Sedentary life style.

\section{DISCUSSION}

PCOD is one of the reasons for ovarian dysfunction, in which patients have multiple cysts in their ovaries that occur due to disruption in normal menstrual cycle. Ovaries get enlarged and produce excess amounts of androgen and estrogen these hormones interfere with the growth and release of the eggs from the ovaries leading to anovulatory cycle and irregular menstruation .which directly affects the fertility potential of women. Panchakarma and Ayurvedic medicine acts at the root level can brings backs deviation of hormonal system back to normalcy. Vamana Karma will reduce Saumya Guna, resulting into relative increase in Agneya Guna of Sharira increasing the Pramana of Artava. Pushpadhanwa rasa was given as it has Tridosha samaka property. The ingredients has a property of vajikarana, rasayana, ayusya, putra prada, balya, manashanthi kara, manodosha hara, garbhakrut . Ashwagandha Ksheerpakaa as Rasayanam and Garbhasthapana and also help to reduce the stress and anxiety level.

\section{CONCLUSION}

PCOD occurs due to an imbalance caused by any of the three Doshas which effect the fertility of the female .PCOD effects the hormones level in the body and causes the increase of Kapha Dosha and causes the formation of the multiple cysts in ovaries anovulatory periods and the symptoms .Vamana Karma helps in Strotas Shudhi and help in the kapha disorders. Pushpadhanwa rasa act on the Manashanthi and Garbhakrut. Ashwagandha Ksheerpaka acts as Garbhasthapaka and Rasayana. The present study reveals the effective management of infertility associated with PCOD was managed by Shodana and Garbhasthapaka oushadhi.

\section{REFERENCES}

1. Dutta .D.C.,textbook of obstetrics chapter 16 edited by Hiralal Konar,New central book agency $(P)$ Ltd.Reprint edition, 2006; 220.

2. Shushrut, Shushrut-Samhita, Sharisrsthana 2/35 Hindi Commentary by Kaviraj Ambikadatta ShastriSanskrit Sansthan Publication Varanasi, Reprinted in 2006; 15.

3. Astanga Hridaya of Vagbhata,Edited with the vidyotini hindi commentary by Kaviraja Atrideva Gupta,Edited by Vaidya Tadunandan Upadhayaya,Sharira Shana 1/8-9,Published by Chukhamba Sanskrit Sansthan,Varanasi.

4. Harita Samhita tritaya 48/1-6, Edited with the Hari commentary by Pt.Harihar Prasad Tripathi Published by Chaukhamba Sanskrit Sansthan, Varanasi.
5. Tivari $P V$. 2nd ed. Varanasi: Chaukhambha Orientalia; Ayurvediya Prasuti-Tantra and StriRoga, 1999; 1; 14

6. Shushrut, Shushrut-Samhita, Sutrasthana 17/12 Hindi Commentary by Kaviraj Ambikadatta Shastri, Sanskrit Sansthan Publication Varanasi, Reprinted in, 2006; 72.

7. Dutta D.C, Text book of gynecology including contraception; Amenorrhea; Chapter 28; Fifth Edition: Kolkata; New Central Book Agency (P) Ltd. 2008, Revised Reprint: 2009. P-440.

8. Dutta D.C, Text book of gynecology including contraception; Amenorrhea; Chapter 28; Fifth Edition: Kolkata; New Central Book Agency (P) Ltd. 2008, Revised Reprint: 2009. P-440-443.

9. Premvati Tewari, Ayurvediya Prasuti Tantra Evam Stri-Roga, Part II, 2 nd Ed., published by Chaukhamba Orientalia, Varanasi, Drutiyadhyaya. 2000; 163-167. 9

10. Premvati Tewari, Ayurvediya Prasuti Tantra Evam Stri-Roga, Part I, 2nd Ed., published by Chaukhamba Orientalia, Varanasi,Shashtamadhyaya 2007; 310. 